\title{
¿Qué quiere Dios?
}

\author{
God on trial | Andy de Emmony | 2008
}

\author{
Eduardo Laso*
}

Universidad de Buenos Aires, Argentina

Recibido: 19 de noviembre 2018; aceptado: 10 de febrero 2019

\begin{abstract}
Resumen
Un grupo de judíos de diverso origen son encerrados en una barraca de Auschwitz. Saben que serán ejecutados en una cámara de gas al amanecer. Confrontando su sombrío destino, se preguntan por qué Jehová no los ayuda. Alguien acusa a Dios de haber roto la alianza con el pueblo judío. El debate adquiere la forma de un juicio a Dios, para determinar si es culpable o inocente de traicionar al pueblo elegido. Juicio a Dios pone en escena el problema de la posición del hombre confrontado al horror, la crueldad y la injusticia. Pero sobre todo ante la figura de Dios y las diversas posibles respuestas -denegatoria, cínica, desesperada o ética- ante su ausencia.
\end{abstract}

Palabras Clave: Acto ético | Dios | Holocausto | Trauma

What does God want?

Abstract

A group of jews from different origins are shut-in a barrack of Auschwitz. They are aware that they will be executed in a gas chamber at dawn. Confronting their somber destiny, they wonder why Jehova doesn't help them. Someone accuse God for having broken the alliance with the jew people. The debate acquires the form of a judjement to God, so as to determine if he is guilty or innocent of betrayal to the Chosen People. God on trial staged the problem of the position of man confronted to horror, cruelty and injustice. But above all to the figure of God, and the varied possible respons -denial, cinical, despare, étical-in the face of it's absence.

Key Words: God | Ethic act | Holocaust | Trauma

Dirigida para la televisión por Andy de Emmony, God on Trial (2008) narra el improvisado juico a Jehová que llevan a cabo prisioneros judíos en una barraca de Auschwitz. A pocas horas de ser llevados a las cámaras de gas, se inicia entre ellos un debate en torno del destino que les espera y algunos se preguntan por qué Dios lo permite. Ante el enojo de algunos a semejante cuestionamiento a Jehová, proponen ordenar el debate en forma de un proceso dirigido a Dios, bajo la acusación de haber roto la alianza con el pueblo de Israel, al permitir que los nazis lleven a cabo la Shoah.

La obra se inspira en El juicio a Dios, de Elie Wiesel. Fruto de una crisis de fe como consecuencia de su experiencia como prisionero de un campo de concentración, Wiesel escribió una historia ambientada en un pueblo de Ucrania en 1649, donde un pogromo cosaco acabó con casi todos los judíos de la ciudad. Los dos únicos sobrevivientes, en vez de montar una obra de Purim, deciden juzgar a Dios. Uno de ellos acusa a Dios de hostilidad, crueldad e indiferencia por haber abandonado a su pueblo cuando lo necesitaba. El único que acude a defender a Dios es un extraño que resulta ser el demonio. Aunque la obra se sitúa en el siglo XVII, Wiesel ha dicho que se basa en un evento del que fue testigo en Auschwitz, cuando tres rabinos se reunieron para acusar a Dios por permitir que ocurra el Holocausto. "Sucedió a la noche. Había sólo tres personas. Al final del juicio, emplearon la palabra chayav, en vez de "culpable". Significa "Él nos debe algo". Luego nos fuimos a rezar”.

\section{Dios y Job}

La historia está influida por el Libro de Job en el Antiguo Testamento, donde Dios es acusado por Satanás de comprar la fidelidad de Job a cambio de salud y prosperidad. Como respuesta, Dios le permite al diablo probar la lealtad de Job mediante una serie de terribles infortunios. 
Al comienzo de las catástrofes, Job reacciona con estoica tolerancia. Pero su dolor y amargura son tan grandes que, al final, se derrumba y acusa a Dios por los agravios. Los amigos de Job salen en defensa de Jehová y le dicen que seguramente debe merecer el sufrimiento que padece. Suponen que debe haber un vínculo entre sus desgracias y alguna falta moral que se niega a confesar. Dios no puede ser cruel, por lo que el sufrimiento humano es consecuencia de las faltas del hombre, que cosecha lo que siembra. Dios no puede castigar el bien ni premiar la maldad. De modo que los amigos de Job le imputan mala fe y encubrimiento, mientras este grita su inocencia.

Pero Job no reclama por el abandono de Dios, sino que sólo pide que lo deje en paz: “¿Qué es el hombre para que lo engrandezcas, para que te preocupes por él, para que lo examines cada mañana, y a cada momento lo pongas a prueba? ¿Nunca apartarás de mí tu mirada, ni me dejarás solo hasta que trague mi saliva? ¿He pecado? ¿Qué te he hecho a ti, oh guardián de los hombres? ¿Por qué has hecho de mí tu blanco, de modo que soy una carga para mí mismo?" (Job 7:17). Variante de la pregunta que el sujeto le dirige al Otro: ¿Che vnoi?, ¿Qué me quieres?

Al final del Libro de Job, Dios habla. No le explica a Job por qué lo dejó sufrir en manos de Satanás. Interpela a Job, haciendo exhibición de su poder y grandeza: “¿Dónde estabas cuando yo hice el mundo? ¿Puedes comprender cómo lo hice? ¿Puedes hacer lo que hice yo? (...) Si soy suficientemente poderoso y sabio para crear Orión en el cielo nocturno, un buey salvaje y un avestruz, ¿puedes confiar en mí mientras atraviesas el problema que permití en tu vida?”. El universo se ofrece como prueba de sabiduría y poder de Dios, poniendo a Job de rodillas. Las evidencias de su poder y sabiduría evidenciadas en la creación son prueba suficiente para descartar las acusaciones en su contra. Como final feliz, a Job se le dio el doble de lo que perdió y vivió 140 años más.

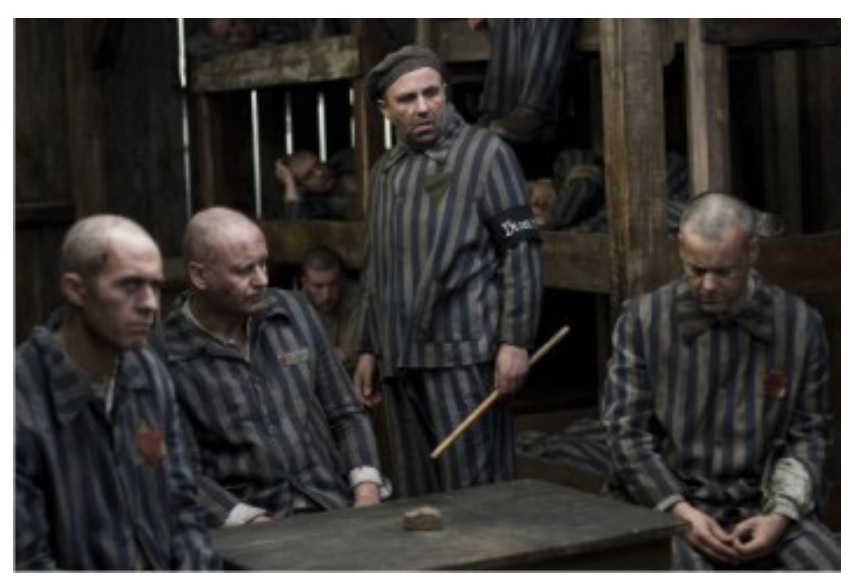

Se ha debatido acerca de si ocurrió o no realmente el juicio a Dios. Fuera del comentario de Elie Wiesel, no hay pruebas testimoniales del episodio que narra el film. Sin embargo podemos plantear que este juicio a Dios es estructural: desde el reclamo de Jesucristo "¿Padre por qué me has abandonado?" al freudiano "Padre, no ves que estoy ardiendo".

El campo de concentración conformó un espacio mortífero en el que se anularon todas las marcas simbólicas que organizaban la vida de los afectados. El arrasamiento traumático tiene como efecto de reenviar al sujeto a un punto de desamparo primordial. Una respuesta a este arrasamiento del marco simbólico es el esfuerzo por ligar aquello que se presenta como acontecimiento no simbolizado. ¿El sujeto puede salir de la posición de ser un objeto deyecto del mundo, repitiendo la operación alienación-separación, por vía del Che vuoi? dirigido al Otro. Se trata de una interrogación sobre el Otro que apunta al más allá de lo que dice, hacia lo que desea. La operación de separación ataca la cadena significante por vía del planteo: "me dices esto, pero, ¿qué quieres?”. God on trial recorre la pregunta ¿Qué quiere Dios al permitir la Shoah?, bajo la forma de un tribunal en el que se juzga el deseo del Otro.

\section{Judaismo y Jahvéh}

Tomemos algunas consideraciones sobre el judaísmo que plantea Daniel Sibony en su libro Los tres monoteísmos, como modo de situar a aquellos que en el film deciden juzgar a Dios. ${ }^{1} \mathrm{El}$ "pueblo elegido" es, estrictamente hablando, un pueblo elector, dado que los judíos son el primer pueblo en elegir al Ser como Dios. Y el Ser, origen de todo lo que es y fuente de todo lo que puede ser, es Uno. Esta elección será posteriormente adoptada por el cristianismo y el islamismo, reconociendo ambos a los judíos como los primeros, para luego adoptar posiciones hostiles al judaísmo (sea por no reconocer la llegada del Mesías o del Profeta, o por traicionar la palabra de Dios -como si se pudiera no traicionarla). Este Ser es Verbo. El Ser habla. Y su Palabra adquiere forma de nominación, llamado, mandato, recuerdo, deseo, abriéndose a una serie potencialmente infinita.

El Nombre de Dios no puede ser pronunciado. Lo que no impide que pueda escribirse y plasmarse en las letras: YHWH constituye el tetragramaton del Nombre de Dios. Dado que no existían las vocales escritas en el 
idioma hebreo antiguo, su pronunciación exacta se perdió. Por lo que Yabweh, Yavé, Yah, Jehová, Iehová son pronunciaciones posibles.

El significado del nombre de Dios describe su propia naturaleza. El verbo hebreo hayah designa una presencia viva y activa. Su conjugación significa: "Yo existiré por mí mismo" o "Yo soy el que existe por sí mismo". Yabveh sería una combinación de las formas de pasado, presente y futuro de la raíz del verbo ser, para indicar la eternidad de la existencia divina. Así, YHWH (Jahvé) significa el ser habiendo sido a-ser. Asimismo "el que causa el ser", "Él, que hace existir". Por permutación de las letras del tetragrama, obtenemos:

$$
\begin{aligned}
& \text { HWYH }(\text { havaya })=\text { el ser } \\
& \text { WHYH }(\text { vébaya })=\text { esto fue o esto será } \\
& \text { YHWH }(\text { yébove })=\text { esto está presente }
\end{aligned}
$$

De modo que el tetragrama es el lugar de las tres modalidades de tiempo -pasado, presente y porvenir- llevadas por el Ser de presencia innombrable, que sobrepasa todo nombre y todo lo que es. YHWH es nombre propio del ser-tiempo, el Ser que deviene nombrando o el devenir nombrando el Ser. Y también es el devenir parlante del ser, en tanto el Ser es verbo. YHWH es el nombre del cual derivan todos los demás. De ahí que es Nombre del Padre como fundante de toda metáfora, de toda nominación. YHWH es un Nombre infinito, un potencial de nombres y el lugar de lo que da lugar.

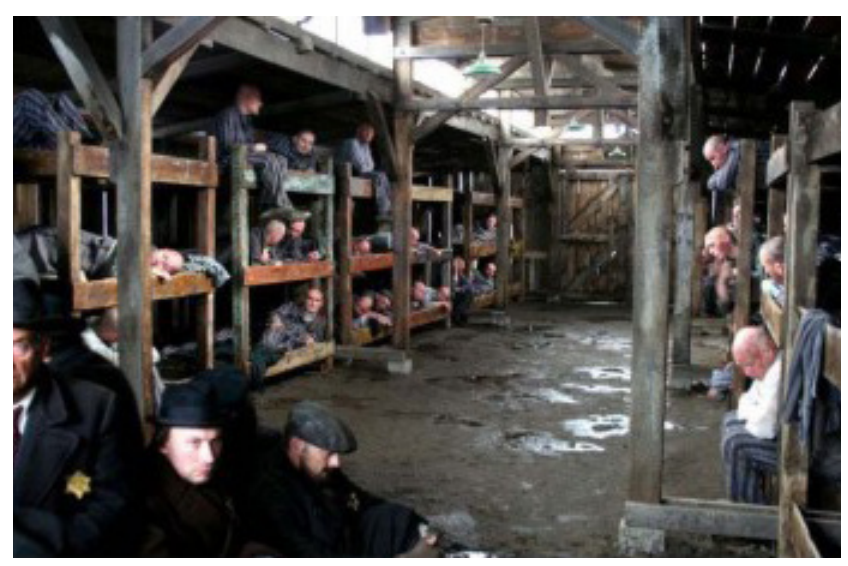

Este Ser que se hace parlante, se sitúa en un ciclo temporal. Su palabra pone en marcha la entrada en el tiempo y un ciclo de transmisión. El Ser que es Verbo se dirige a lo que es, que es finito y carece de ser propio. Le habla a alguien: le exige al ser humano una manera de estar presente que implique ser sensible al paso del tiempo. Se trata de una llamada a ser.
La relación a Dios hace que todo lo que existe esté afectado por una carencia de ser, en contraste con el Ser mismo. Esta carencia es irreductible y se transmite (por ejemplo, entre las llamadas del Ser y lo que pueden entender los seres humanos, entre la ley y su cumplimiento, etc.). Esta falta que el hombre descubre en relación con el Ser puede soportarla y asumirla como castración inherente al parlétre, o imputarla a otros, o a sí mismo.

En el caso del pueblo judío, esta relación al Verbo tuvo el efecto de estar en conflicto con Dios. Para el judío transmitir su mensaje, traicionarlo, perderse y reencontrarse en él, serle fiel y faltarle, establecer una Alianza y faltar a ella, pasó a formar parte de la misma relación con Dios. Israel aparece como nombre tras el combate de Jacob con el ángel. Significa "el que combate con Dios". El abismo entre el Ser y lo que es, es vivido como una guerra de amor. El combate es un retroceso de la alianza, la cual debe permanecer cueste lo que cueste. El equivalente a la guerra del amor en el lenguaje es el perpetuo preguntarse, el existir como una pregunta, hacer depender la existencia de aquel origen que falta.

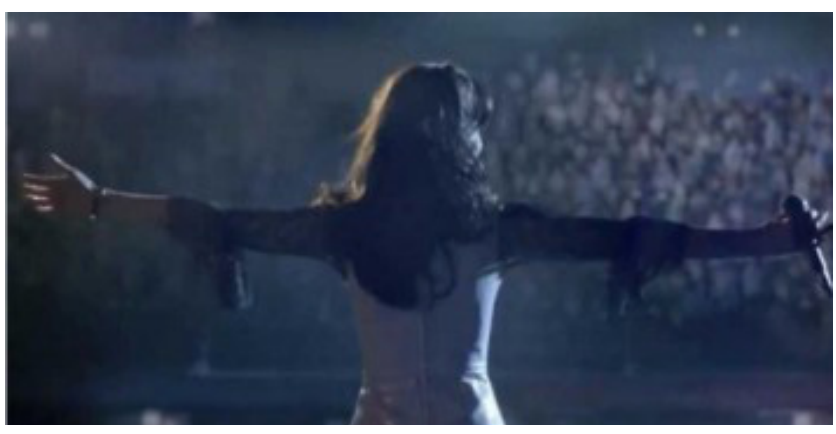

Como es imposible de colmar el abismo en el origen de la relación del Ser con lo existente, se trata de transmitir los puntos de origen marcados por la carencia, a la espera de que al fin de los tiempos se recobre la plenitud. Para elaborar la pérdida en el origen e instaurar un intercambio con Dios, el cuerpo humano debe ser liberado de la carencia. El ritual del sacrificio organiza el desplazamiento de las faltas del primer hijo en el animal, de modo de salvar al primero señalándole a Dios una pérdida más simbólica, es decir, desplazando la pérdida. Es, por ejemplo, el resultado del sacrificio de Abraham, en el que Isaac es sustituido por un carnero. Este estar perdido y escaparse de la pérdida por su desplazamiento se pone en juego tanto en el mesianismo (sueño de ser salvado) como en el ejercicio de la interpretación, práctica en la que se pierde el sentido y se lo recobra. Es estar perdido y reencontrarse sabiendo que no se reencuentra 
la pérdida original y no hay manera de salvarse definitivamente.

La Alianza entre el hombre y el Ser se funda en una ley que desvía la carencia al señalarla en la alternancia de los olvidos y los recuerdos. La Alianza consiste en transmitir las llamadas a ser, el doble movimiento en el que se pierde el origen, se recobra, se localiza. Guerra de amor con el Ser, el cual lanza una insistente llamada a querer al ser. Es decir, querer lo que hace ser todo lo que es, no elegir la nada o la muerte.

La llamada "tierra prometida" no es un lugar geográfico entre Egipto y Líbano. Se trata de una relación simbólica: se es de la tierra por haber sido llamados -prometidos- a estar en ella en la experiencia del ser y del tiempo.

\section{Dios procesado / Dios a prueba}

God on Trial se inicia en el presente, en un Auschwitz convertido en memorial. Allí un visitante pasa a narrar la historia del juicio. Dado que no hubo sobrevivientes de ese evento y quien lo cuenta no estuvo allí, se trata de un relato que hunde sus orígenes en la incertidumbre y el mito. Se trata de una ficción que se vuelve pasadora de un real. La historia del juicio a Dios plasma un debate en el que se llega al final a una conclusión que implica un cambio de posición de los sujetos participantes en relación al Otro divino.

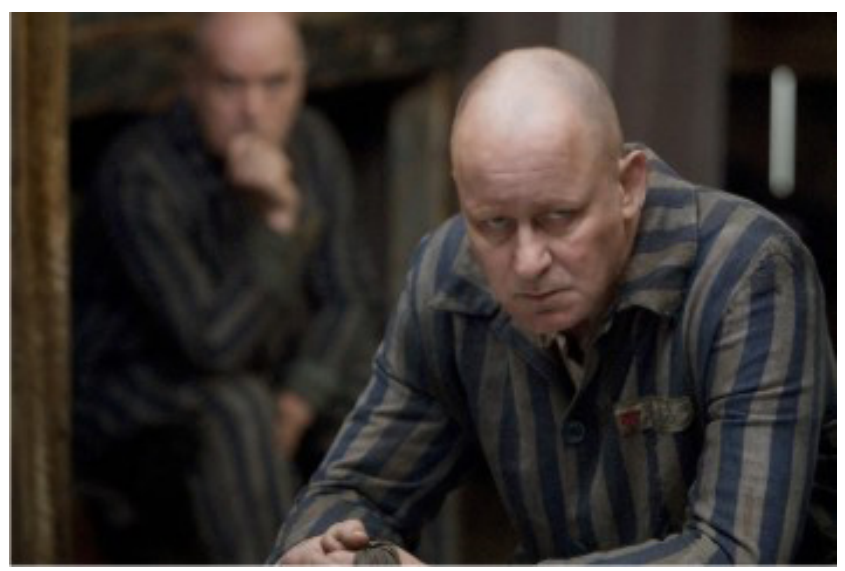

A la llegada a la barraca de los prisioneros, un kapo les da la bienvenida haciéndoles saber que acaban de entrar en un lugar en donde se han dislocado todos los valores. Comenta que antes, en el "otro mundo", él era un criminal condenado mientras que ellos eran profesionales. Pero en Auschwitz él es Dios y ellos son nada. El kapo es la voz del campo, un orden cerrado sin razón ni ley. Su discurso describe la situación en que se encuen- tran los prisioneros: ellos se han caído de la escena del mundo hacia lo in-mundo del campo, un espacio en el que ha desaparecido orden legal que organizaba simbólicamente la experiencia. El discurso del kapo sostiene un Otro absoluto del goce del que él se propone como lugarteniente. Se trata de un fantasma que Giorgio Agamben tematiza en Homo Sacer como la relación entre un bando soberano y la vida desnuda.

¿Qué hacer en semejante situación? Una respuesta es apelar a Dios para dirigirle el reproche por el desamparo, en el esfuerzo de reanudar el vínculo con el Otro, de renovar el pacto simbólico elemental que le permita al sujeto dejar de ser objeto del goce de un Otro malvado. De la desesperación los prisioneros intentan salir mediante la propuesta de procesar a este Otro que no hace nada, bajo la imputación de que ha roto el pacto con su pueblo elegido. Se trata de instalar una escena legal allí donde no hay ley alguna, en el cual el Otro absoluto es emplazado, procesado, puesto a prueba.

Kuhn, uno de los prisioneros más viejos, señala el carácter blasfemo de enjuiciar a Dios, pero otro prisionero recuerda que lejos de eso, la lucha con Dios es parte misma de la tradición religiosa hebrea, como lo indica el nombre Israel. Un juicio a Dios es, indirectamente, un modo de reafirmar el nombre propio como pueblo de Dios: sólo el pueblo elegido puede juzgar a su elector.

Se dispone entonces la barraca de modo de armar el espacio simbólico de un proceso judicial, con un juez, un abogado por la defensa y otro por la fiscalía. La Torá se hace presente a través de uno de los prisioneros que es capaz de recordarla. El cargo que se le imputa a Dios es "incumplimiento de contrato con el pueblo elegido", dado que los judíos desde Moisés tienen una alianza con él, por la cual el pueblo obedecería su ley y éste los protegería y garantizaría su supervivencia.

El curso del juicio sigue una dialéctica de argumentos y contraargumentos en la que se irán sucediendo diversas figuras del gran Otro. La primera solución al problema teológico de cómo es posible la Shoah, en la que el pueblo elegido, es elegido para ser exterminado -problema que abre la cuestión de la posición de Dios ante este acontecimiento catastrófico- es hacer recaer la falta en los afectados. El Holocausto es un castigo de Dios a los judíos por haberse alejado de él. Como en épocas pasadas, se trata de una nueva prueba de fe por la que Jehová hace pasar a los judíos. Es lo que planteará Kuhn, el padre religioso enojado con su hijo por haberse apartado de la fe. "Antes de culpar a Dios, debemos mirarnos a nosotros mismos. No es Dios quien incumple el pacto, sino 
nosotros. Se trata de un castigo. Algunos judios le ban dado la espalda a la Torá. Nuestros hijos se han ido a las cindades. Se volvieron socialistas o sionistas, capitalistas o anarquistas. Olvidándose de las Escrituras". El discurso del padre describe especialmente la situación histórica de los judíos alemanes, quienes durante el siglo XIX llevaron a cabo un proceso de asimilación, dejaron la religión de sus antepasados y se integraron a la sociedad alemana abandonando costumbres, ritos y marcas judías. Con la llegada del racismo nazi en el siglo XX, los judíos alemanes descubrieron que hicieran lo que hiciesen, serían siempre judíos: su identidad ancestral renegada les retornó desde el Otro racista.

La hipótesis de la Shoah como castigo divino porque habrían sido los judíos quienes rompieron el pacto es rápidamente puesta en cuestión: las masacres nazis no diferenciaron entre judíos no practicantes y judíos religiosos, respetuosos de la Torá. Dios por lo tanto estaría castigando indiferentemente a buenos y malos judíos. Para colmo no castiga a seres malvados como Hitler. Y la existencia de niños en el campo, vale decir, de inocentes, es inconsistente con un sentido elemental de justicia. La Shoah se presenta así como un exceso criminal que resulta incomparable y desproporcionado con un supuesto crimen o falta atribuible al pueblo judío.

La defensa religiosa que ensaya el rabino es sostener que el castigo de Dios no es proporcional. Vale decir, no tiene medida (por ejemplo, el diluvio universal), y que es un error hacer de la Shoah algo personal: Dios no actúa contra la persona, sino hacia el pueblo judío en general. Sólo que una vez que se plantea la impersonalidad de Dios, ¿qué sentido tendría un vínculo con aquello que es impersonal? Como dice el fiscal: un dios que no es personal es el estado del tiempo y nada más.

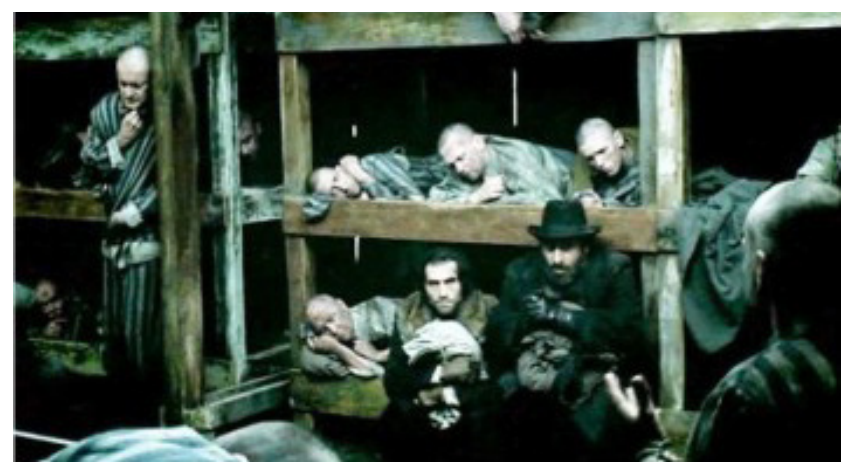

El rabino Schmidt invierte entonces el sentido de la Shoah, de castigo en sacrificio, como otra manera de sostener a Dios. Plantea a la Shoah como "holocausto", en el sentido sagrado de un sacrificio a Jehová, una pu- rificación mística que resulta insondable para la mente humana. La Shoah no sería un castigo contra los judíos, sino una purificación. Es la metáfora del Dios cirujano que, por amor, amputa una pierna gangrenada para que el cuerpo siga viviendo. Si Dios permite que mueran los justos, es porque en un holocausto, lo que se ofrece a Dios en sacrificio, es lo mejor que se tiene. El sufrimiento pasa así a formar parte del plan divino, y el pacto no solo no estaría traicionado sino que atravesar la Shoah forma parte del mismo. Incluso afirma que algo bueno puede llegar a salir de todo eso: el propio Mesías o un retorno a Israel: "Somos afortunados de estar purificando al pueblo a través de nuestro dolor. No dejen que les quiten su fe. Hitler morirá. La guerra terminará. El pueblo y la Torá vivirán. Por lo tanto, debemos confiar en Dios". La solución del rabino es que Dios sabe lo que hace, y que el dolor, la muerte y el horror de los campos deben ser aceptados como parte de su plan. No son por lo tanto prueba de que Dios traicionó el pacto.

La consecuencia masoquista de esta forma de hacer de la Shoah un Holocausto sagrado es que entonces Hitler pasaría a ser el instrumento del plan de Dios, y por lo tanto no habría que luchar contra el nazismo. Hasta incluso deberían ir contentos a las cámaras de gas, lo cual es una implicación absurda. Pero además, no es lo mismo elegir ser un mártir, que ser martirizados. En la Shoah no hay elección para los judíos. Y además se los asesina por cuestiones de raza, no de fe.

En ese momento se hace hablar al kapo, quien encarna la moral cínica de la pura supervivencia como forma del mal. Como quiere vivir, no le importan los medios para ello, aunque su vida dependa de mandar a miles a las cámaras de gas. Él es el ejemplo paradigmático de los que sobrevivirán al genocidio: los peores, los mezquinos, los viles, los egoístas, los crueles. Seres con los que no se podría construir una nación sabia y justa. "¿Qué clase de Mesías querrá a estos como su pueblo? ¿Qué tipo de Israel será construido por tal gente?"

El fiscal introduce entonces la clásica paradoja del Dios justo y todopoderoso. Si es todopoderoso, habría podido purificar a su pueblo sin tener que gasearlos, $y$ habría detenido el genocidio. Pero como el genocidio no se detiene, entonces o no es justo o no puede detenerlo $\mathrm{y}$ entonces no es todopoderoso. Es el planteo del historiador del holocausto Yehuda Bauer: es imposible que pueda existir un Dios todopoderoso y justo, ya que si es todopoderoso es Satán, y si es justo es un nebbish. Un dios al mismo tiempo todopoderoso y justo no habría permitido el asesinato de inocentes por ninguna razón 
o plan. Si es todopoderoso podría haber intervenido, y si es justo habría debido intervenir. Pero si no lo hizo y es todopoderoso entonces es Satán. Y si es justo no puede ser muy poderoso, porque en ese caso habría querido intervenir, pero no tuvo poder para modificar las cosas. Es entonces un Dios bienintencionado pero nebbish, un pobre tipo que necesita que lo mantengan, un Dios que necesita obtener su fuerza de nosotros. Dios como nebbish, un Otro que existe porque nosotros le damos existencia, se aproxima a lo que plantea Freud desde el psicoanálisis: la religión como ilusión que sostiene un padre que ampara, según nuestro deseo.

La respuesta religiosa a la ausencia de la intervención de Dios es el argumento del libre albedrío. Dios no es ni impotente ni injusto, sino que ha limitado su propio poder para darle al hombre el libre albedrío. Si Dios no permite que el hombre elija el mal, no habría posibilidad de un mundo en el que la decisión ética tenga sentido. Si hay mal en el mundo es porque Dios le dio al hombre la libertad de elegir. La existencia del mal no es producto de Dios sino del hombre.

El argumento de la libertad humana, sin embargo, deja a Dios en una curiosa posición desde la perspectiva religiosa: Dios es un espectador de nuestras acciones pero no participa. Está ahí mientras se cometen los crímenes. Elie Wiesel, concluye respecto de esto que su pasividad es complicidad, no muy diferente de la de tantos alemanes comunes que permitieron que la Shoah ocurriese. Ante un Dios-espectador, su existencia es por lo tanto indiferente a los humanos. Al punto que no tendría sentido rezarle.

El personaje de Lieble presenta la paradoja de que la libertad humana, formal y general, se plasma en el mundo de formas en las cuales la libertad de unos coarta las de otros. Así, por ejemplo, la libertad del oficial nazi de matar a sus hijos y de ofrecerle perversamente a él como padre que elija a uno de ellos para que se salve es el ejemplo dramático de una elección imposible, tan bien plasmada en el film La decisión de Sophie.

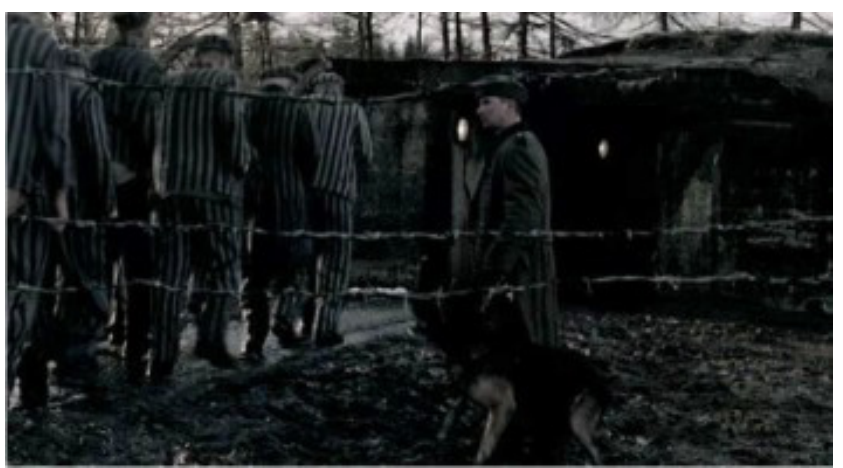

La respuesta religiosa a la figura de Dios voyeur, es sostener que Dios está junto a su pueblo, sufriendo como una víctima más. Solo que un Dios sufriente, "cristico", no sirve de nada en la medida en que ese sacrificio no sustituye a los judíos. La muerte de Cristo se presenta como un modo de saldar una deuda de sangre del hombre con Dios. En cambio un Dios gaseado junto con su pueblo elegido ¿̇es un Dios salvífico? Como dice el fiscal: "¿Quién necesita a un Dios que sufre? Necesitamos un Dios que le envíe el ángel de la muerte a nuestros enemigos".

Lieble interviene entonces con ejemplos en los que en el medio de la catástrofe se produce un acto humano bondadoso. Le señala al fiscal que se pregunta una y otra vez de dónde proviene toda esta maldad. Pero también cabe preguntarse de dónde proviene toda esta bondad. Bondad y maldad se vuelven expresiones posibles del gran Otro, que se torna insondable y grandioso.

Llegados a este punto del proceso, alguien señala que la existencia del pueblo judío no está garantizada y puede desaparecer. Uno de ellos señala: "Debemos considerar la posibilidad de que nosotros, en esta sala, seamos el santo remanente. Por eso es importante lo que decidamos. Si somos los últimos, podemos terminar la historia. Podemos terminarla aqui, la historia que comenzó con Moisés en el Sinai hace 3500 años. Podemos terminarla, podemos romper el pacto". Ya no se trataría de si Dios rompió la alianza con su pueblo, sino la inversión dialéctica del planteo: la decisión del pueblo judío -representado en ese grupo humano- de romper el pacto.

Resulta significativo que en ese contexto tome la palabra el científico Jacques para sostener que no hay pacto alguno que romper, porque Dios es una ilusión, empleada como estrategia de poder desde los judíos hasta Hitler. La posición a Freud en El porvenir de una ilusión y a Marx y el planteo de la religión como opio de los pueblos. Tampoco falta Darwin con el argumento de la avispa: "Existe una avispa. Se le denomina Ichneumonidae. Pone sus huevos dentro de las orugas. Los huevos nacen $y$ luego las larvas de la avispa se comen la oruga desde el interior. Comen para salir fuera de esta. ¿Qué clase de Dios diseñaría algo asi?". La naturaleza es ciega a las cuestiones del bien y el mal. La naturaleza es una figura del goce mortífero. Por lo tanto no es posible que exista Dios como figura bondadosa. La pregunta “ ¿Qué clase de Dios diseñaría algo así?” la respondería el marqués de Sade: un Dios infinito en maldad, al que habría que servir como instrumento para lograr participar de ese goce en el mal. 
Es lo que va a plantear la intervención de Akiba, que es la que decide finalmente al tribunal declarar culpable a Dios: el recorrido de la historia de Jehová y los judíos en el Antiguo Testamento (el diluvio, las plagas de Egipto, el sacrificio de Isaac, la conquista de Canaán) y por qué nunca fue un dios bueno, sino un Dios que sólo estuvo del lado de los judíos. Sobre la conquista de Canaán por los Israelitas, que resultó en la masacre de medianitas y amalekitas dijo el historiador Yahuda Bauer: "Como judío, debo vivir con el hecho de que la civilización que heredé... incluye el llamado al genocidio en su canon."

En un testimonio conmovedor que reivindica al hombre como potencia de eticidad, Akiba plantea: "Debimos haberle enseñado a nuestro Dios la justicia que había en nuestros corazones. Debimos haberlo enfrentado. Él no es bueno, simplemente ha sido fuerte. Simplemente ha estado de nuestro lado. Él sigue siendo Dios... pero no nuestro Dios. Se ha convertido en nuestro enemigo. Eso es lo que le ha sucedido al pacto. Ha hecho un nuevo pacto con otros". El discurso de Akiba plantea las consecuencias de la fidelidad ciega al gran Otro: el sujeto deviene así instrumento del goce del Otro. Posición perversa ante la que el deber ético es oponerse. Resistir a la alienación al gran Otro y la obediencia ciega, en tanto es mortífera: para los malekitas, los canaanitas, los judíos, y hasta los alemanes. La oferta a la voz del Otro en holocausto es una vía perversa. Dice Lacan en Los nombres del Padre: "El dios eterno tomado al pie de la letra, no en su goce siempre velado e insondable, sino en su deseo interesado en el orden del mundo, es el principio en el que el perverso se instala petrificando su angustia". Se sale de la encerrona perversa, en todo caso, yendo más allá del Nombre del Padre, no sin valerse de él.

Antes de esta última intervención, el juez Baumgarten hace un aparte con el fiscal y la defensa que es decisiva para entender el desenlace del film: "les quitaron sus propiedades; les quitaron sus nombres; les cortaron el pelo; se llevaron a sus hijos... esposas, madres...incluso el relleno en sus dientes. Les quitaron todo lo que les hizo ser hombres. No dejen que les quiten a su Dios también. No importa cómo... cuan necio e inútil pueda parecer, el pacto es suyo, les pertenece. Dios es su Dios. Aun cuando no exista. Manténganlo. Dejen algo que no puedan quitarles. De nosotros".

Lo que plantea este personaje es lo que el filósofo Emil Fackenheim postula como el 614 mandamiento de la Torá. Fackenheim propone agregar a la Torá el mandamiento: "Se prohíbe a los judíos dar a Hitler victorias póstumas". Se trata de un imperativo moral por el cual los judíos no deben emplear los hechos de la Shoah para renunciar a Dios, al judaísmo o en el caso de judíos no religiosos, a la supervivencia del pueblo judío, rechazando de este modo darle a Hitler una victoria póstuma. Aceptar el silogismo de Bauer (Satán o nebbish), la aceptación de que Dios abandonó o rechazó a los judíos es dar a Hitler la victoria sobre los judíos, el exterminio de la fe que los liga. Si Dios es Satán, entonces Hitler es Dios. Tal planteo encierra el problema de dar a Hitler una presencia central por negación, en tanto pasamos a referir nuestras acciones en relación a él como principio rector, al modo de: “¿Consideraría Hitler una victoria póstuma si escojo x o y?”. Cualquiera que sea la decisión acerca de la relación entre dios y el mal, entre Dios y la Shoah, y por mucho que no satisfagan los intentos de explicarlo, no se debe permitir que Hitler sea el punto por el cual el pueblo judío rechace a Dios. Se puede rechazar a Dios por cualquier otra razón, pero no por Hitler: no se le debe dar esa victoria póstuma que lo desresponsabiliza por sus crímenes.

\section{Sostenerse desde el rasgo}

El tribunal declara finalmente culpable a Dios por no cumplir la alianza con el pueblo judío. En ese momento irrumpen los nazis para llevarlos hacia las cámaras de gas. En el medio de la conmoción ante la inminencia de la muerte, uno de ellos pregunta desesperado "ahora que Dios es culpable, ¿qué hacemos?”. Para recibir como respuesta: "ahora... ahora rezamos". Dios es culpable de no cumplir con el pacto. Aun así, el pacto se sostiene ya no desde la alienación ciega al discurso del Otro propia del religioso fundamentalista, sino desde un rasgo identificatorio que nombra a Israel como el pueblo elegido que espera su tierra prometida.

Un espectador desprevenido podría suponer que nada ha ocurrido: luego del veredicto de culpabilidad a Dios, siguen rezando. ${ }^{2}$ Sin embargo hay un cambio de posición: de la alienación al Otro absoluto, se pasó a declarar culpable -vale decir, en falta, castrado- a Jehová, para rescatar un rasgo identificatorio que permita mantener una religadura entre aquellos que el nombre de Jehová agrupa como hermanos en un pueblo, a saber, Israel. Ya no se trata de creer en un Otro completo, sino de asumir la castración del Otro y valerse de un rasgo identificatorio para sostener la posición de dignidad y resistencia al Otro gozador que encarna el nazismo. Rezar, ahora que se sabe que Dios (está en) falta, es no 
ceder a aquellas marcas de identidad que el nazismo pretende borrar. La alianza se sostiene entre los hermanos en nombre del Padre muerto, como modo de resistir al goce del Otro.

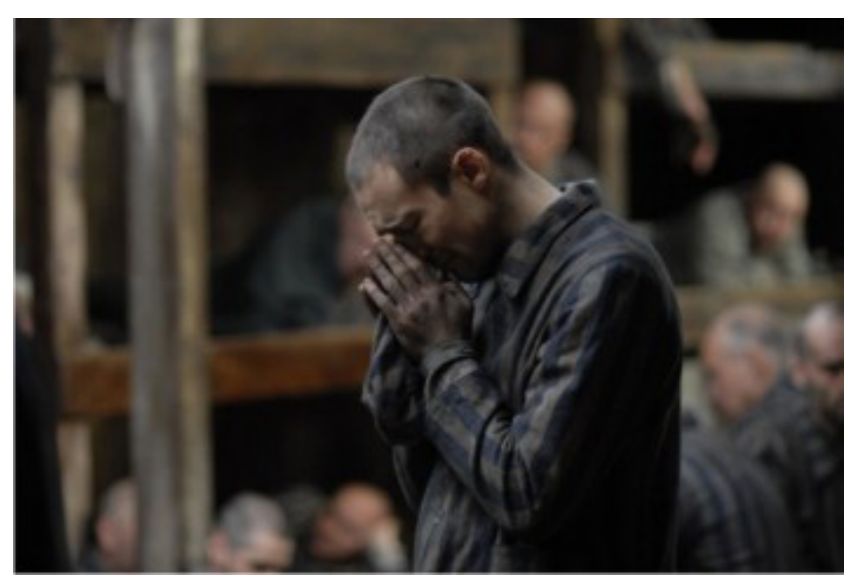

En el medio del caos que se genera en la barraca, un médico nazi va llamando por sus números a los que van a morir. Uno de los llamados es el hijo de Kuhn, que había sido acusado por su padre de haber roto con Jehová. En la desesperación, este padre se sustituye al hijo para salvarlo de la muerte. En ese gesto de un padre que horas antes maldecía a su hijo ateo, hay un acto ético de sostener la continuidad de la descendencia, de bendecirla con la vida y no maldecirla. En vez de que ocurra un milagro divino, un padre reemplaza al hijo rescatándolo de la muerte, para legarle el mandato de que viva y mantener así la continuidad de las futuras generaciones. Este acto en el que un padre hace lo que se esperaba de Dios hacia sus criaturas, transmite un llamado al ser. Frente a un Dios culpable, es responsabilidad del sujeto la decisión por hacer aquello que se esperaba del gran Otro, preservando la cadena generacional.

Al final le preguntan al narrador si fueron respondidas las plegarias de las víctimas. "Todavía estamos aquí" contesta. No se trata aquí de que Dios al final escuchó a su pueblo elegido, conminado por una "condena judicial” de su pueblo. Sino de la decisión del pueblo judío por perdurar. Freud fue ateo, sin embargo se reconocía judío en lo esencial. Lo cual señala que la pertenencia al judaísmo excede el tema de la fe en Dios. La supervivencia del pueblo de Israel no depende de Jehová sino del reconocimiento de una misma pertenencia. Un estar religados por estar atravesados por una misma historia y tradición, una misma adversidad y un anhelo común.

\section{Referencias}

Freud, S. (1990). El porvenir de una ilusión. En Obras Completas, Volumen XXI, Buenos Aires: Amorrortu.

Rosenbaum, R. (1999); Explicar a Hitler. Los orígenes de su maldad. México: Siglo XXI.

Sibony, D. (2004). Los tres monoteísmos. Madrid: Síntesis.

Wiesel, E. (1995). The trial of God. New York: Shocken Books.

Sibony, D.; Los tres monoteísmos: judíos, cristianos, musulmanes; entre sus fuentes y sus destinos, Madrid, Ed. Síntesis, 2004.

2 Cabe señalar que no es lo mismo declarar a Dios inexistente, que a Dios culpable o en falta con el pueblo elegido. 